\title{
Evaluation of litter material and ventilation systems in poultry production: I. overall performance
}

\author{
Valéria Maria Nascimento Abreu ${ }^{1},{\text { Paulo Giovanni de } \text { Abreu }^{1} \text {, Arlei Coldebella }}^{1}$, Fátima \\ Regina Ferreira Jaenisch ${ }^{1}$, Virginia Santiago Silva ${ }^{1}$
}

${ }^{1}$ Embrapa Suínos e Aves, BR 153, Km 110, Caixa Postal 21, 89700-000, Concórdia, Santa Catarina, Brasil.

ABSTRACT - The objective of the present work was to evaluate the performance, mortality and the incidence of lesion on the foot-pad of broilers and litter enterobacteriaceae load in two ventilation systems and two litter materials. The experiment was carried out in four $12 \mathrm{~m} \times 10 \mathrm{~m}$ broiler houses, internally divided in 4 pens, with 200 birds/pen for four consecutive flocks, each one with 42 days of duration and interval of 15 days of downtime between flocks. It was evaluated two ventilation systems (stationary and oscillating fans), and two litter materials (soybean straw and rice husks). Performance variables studied were body weight, weight gain, feed conversion ratio and mortality of birds at 21,35 , and 42 days of age. Flock mortality was daily recorded, and total mortality was used for analysis. Evaluation of lesions by using foot-pad macroscopic examination was performed in all birds at final weighing. It was also performed quantitative examinations of litter enterobacteria. Statistical analyses were performed by using the mixed model theory for repeated measures and logistical regression. Rice husks litter promoted the best performance of birds at all studied ages. Results did not permit to recommend a ventilation system inasmuch as both had similar performances. Soy straw litter causes a high incidence of foot-pad lesions. Enterobacteria occurrence is lower in reused litter.

Key Words: broilers, oscillating ventilation, rice husks, soybean straw, stationary ventilation

\section{Avaliação de materiais de cama e sistemas de ventilação na criação de aves: I. desempenho geral}

RESUMO - Este trabalho foi conduzido com o objetivo de avaliar o desempenho produtivo, a mortalidade, a incidência de lesões no coxim plantar em frangos de corte e a carga de enterobactérias nas camas em dois sistemas de ventilação e dois materiais de cama. O experimento foi realizado em quatro aviários de $12 \mathrm{~m} \times 10 \mathrm{~m}$ para frangos de corte, divididos internamente em quatro boxes/aviário, com 200 aves/boxe, durante quatro lotes consecutivos, cada um com 42 dias de duração e intervalo de vazio sanitário de 15 dias entre lotes. Foram avaliados dois sistemas de ventilação (fixo e oscilante) e dois tipos de material de cama (palhada de soja e casca de arroz). As variáveis de desempenho estudadas foram peso corporal, ganho de peso, mortalidade e a conversão alimentar das aves aos 21, 35 e 42 dias de idade. A mortalidade foi anotada diariamente e, para as análises, foi utilizada a mortalidade total. A avaliação de lesão, por exame macroscópico de coxim plantar, foi realizada em todas as aves na pesagem final. Também foram realizados exames quantitativos de enterobactérias na cama. As análises estatísticas foram realizadas utilizando-se a teoria de modelos mistos para medidas repetidas e a regressão logística. A cama de casca de arroz proporcionou melhor desempenho produtivo das aves em todas as idades estudadas. Os resultados não permitiram recomendar um sistema de ventilação, uma vez que ambos tiveram desempenhos semelhantes. O uso de cama de palhada de soja ocasiona alta porcentagem de lesão no coxim plantar das aves. A ocorrência de enterobactérias é menor em camas reutilizadas.

Palavras-chave: casca de arroz, frango de corte, palhada de soja, ventilação fixa, ventilação oscilante

\section{Introduction}

The use of alternative litter materials, that is, materials other than wood shavings, has become a trend in poultry production. Although it had been demonstrate by several authors that the use of these alternative materials do not interfere with flock live performance, most of them agree that those materials are more difficult to manage and may result in a higher incidence of carcass lesions. According to Elfadil et al. (1996), coarse litter material can cause cellulitis in broilers. Litter reutilization for more than one flock is practiced in several countries. Ávila et al. (2008) tested rice husks, corn cobs, cameroon grass, soybean straws, corn stubble, and saw dust as alternative litter 
materials and concluded that these materials can be used as poultry litter for five or more flocks. Jorge et al. (1997) evaluated the quality of coffee hulls, rice straw, beans straw, and sugarcane residue as litter material in terms of humidity and contamination by coliforms, and did not find any differences in coliform counts. However, aspects relative to the potential health risk posed by these alternative litter materials have been discussed, and their use may limit the international chicken meat trade due to the requirements of showing equivalence of production processes practiced among exporting and importing countries (Silva et al., 2007).

When evaluating food quality and animal welfare, other factors, such as ventilation, should be considered. Ventilation allows changing and controlling air quality by eliminating ammonia, $\mathrm{CO}_{2}$ and other noxious gases, as well as excessive moisture and odor, and, within certain limits, also controlling air temperature and humidity in poultry houses (Abreu \& Abreu, 2000). The commonly used ventilation systems result in deficient air distribution inside the poultry house, producing differences as to mortality and live performance. Fans are currently stationary, and there is no information in literature for possible variations, as for instance, oscillating fans.

Therefore, the objective of the present study was to evaluate the performance, mortality, and foot-pad lesion incidence in broilers and litter enterobacteria load using two ventilation systems and two litter materials.

\section{Material and Methods}

The experiment was carried out at the experimental field of Suruvi, which belongs to Embrapa Suínos and Aves, Concórdia, Santa Catarina, Brazil. Four $12 \mathrm{~m} \times 10 \mathrm{~m}$ broiler houses were internally divided in four pens each (total of

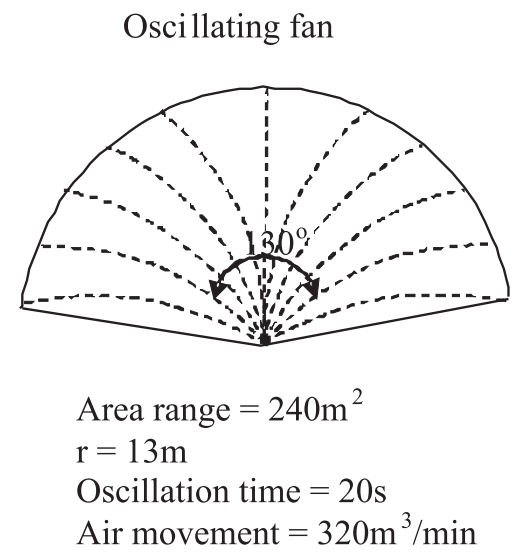

16 pens), at a density of $200 \mathrm{birds} /$ pen $\left(28 \mathrm{~kg}\right.$ meat $\left./ \mathrm{m}^{2}\right)$, totaling 3,200 birds/flock. Four consecutive flocks were followed up. Each flock was reared to 42 days of age, and an interval between flocks (downtime) of 15 days was applied.

Two ventilation systems (stationary or oscillating), reaching a distance of $10 \mathrm{~m}$, and two litter materials (soybean straw or rice husks) were tested. Rice husks and ventilation system using stationary fans are considered as standards as they are commonly used in broiler production. Fans were activated by a thermostat when the environmental temperature was $25^{\circ} \mathrm{C}$, and they were equipped with a potentiometer and speed regulator matching the broiler house size (Figure 1). Treatments were distributed as follows (Figure 2): house 1 - stationary ventilation system, pens 2 and 3 with soybean straw; pens 1 and 4 with rice husks; house 2 - oscillating ventilation system, pens 2 and 3 with soybean straw; pens 1 and 4 with rice husks; house 3 oscillating ventilation system, pens 1 and 4 with soybean straw; pens 2 and 3 with rice husks; house 4 - stationary ventilation system, pens 1 and 4 with soybean straw; pens 2 and 3 with rice husks.

Birds and feeds were weekly weighed and the following parameters were evaluated: body weight, weight gain, feed intake and feed conversion ratio when birds were 21,35 and 42 days of age. Performance data were analyzed according to the theory of mixed models for repeated measures, considering the effects of flock, ventilation system, litter material, bird age, and the interaction of these parameters up to third order, and 16 types of variance and covariance matrices, using PROC MIXED procedure of SAS statistical package (SAS Institute Inc., 2003), according to Xavier (2000). The variance and covariance structure used for analysis was chosen based on the lowest value of the Akaike Information Criterion (AIC). The estimation method was the restricted maximum likelihood.

\section{Stationary fan}

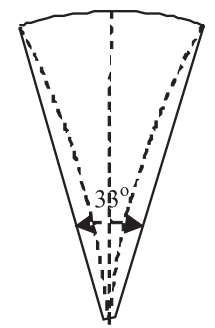

Area range $=134.40 \mathrm{~m}^{2}$

$\mathrm{r}=20 \mathrm{~m}$

Oscillation time $=20 \mathrm{~s}$

Air movement $=320 \mathrm{~m}^{3} / \mathrm{min}$

Figure 1 - Fan traits. 


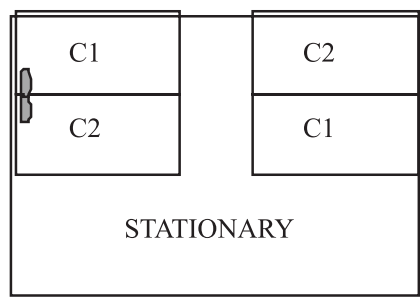

Broiler house 4

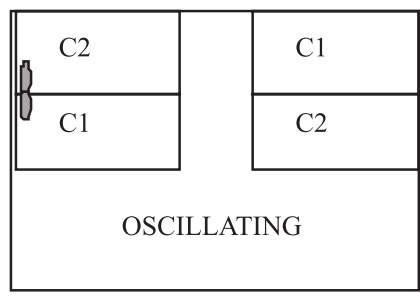

Broiler house 2

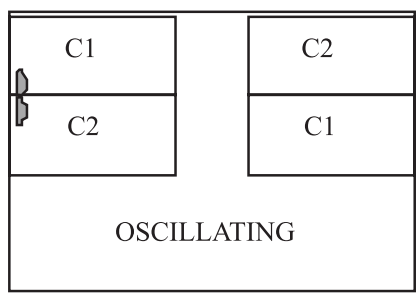

Broiler house 3

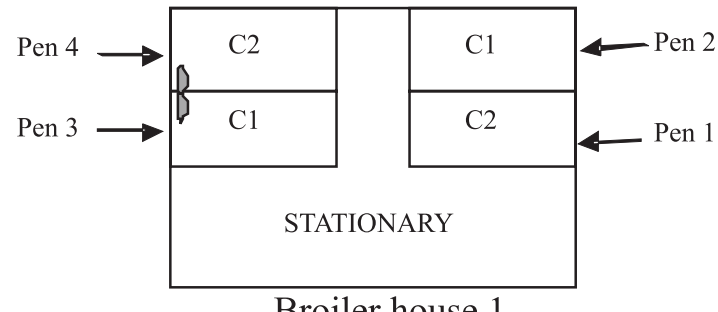

Broiler house 1

Figure 2 - Fan (stationary and oscillating) and litter material (C1 - soybean straw and $\mathrm{C} 2$ - rice husks) distribution in the experimental facilities.

Mortality was daily recorded and assigned to ascitis, sudden death, or other causes. Total mortality was also evaluated. Breast and foot-pad lesions were evaluated by gross examination at the last time that birds were weighed, and scored as present or absent. Because mortality and presence of foot-pad lesion data have binomial distribution, these data were analyzed by logistic regression, using the LOGISTIC procedure of SAS statistical package (SAS, 2003), and considering the effects of flock, litter material, ventilation system, and their interactions. The overdispersion of the presence of foot-pad lesion was adjusted by the dispersion parameter estimated by Pearson's $\chi^{2}$ statistics divided by degrees of freedom.

Litter samples were collected at each flock, when chicks were housed (day 0 ) and when they were removed (day 42), and submitted to enterobacteria quantitative exam. Litter samples weighing $10 \mathrm{~g}$ were diluted at 1:10 in PBS (phosphate buffer saline solution) and serially diluted to $10^{-7}$. Aliquots of $100 \mu \mathrm{L}$ of $10^{-3}$ to $10^{-7}$ dilutions were seeded in Mac Conkey agar and incubated at $37^{\circ} \mathrm{C}$ for $48 \mathrm{~h}$, and submitted to colony-forming unit (CFU) counting in plates containing 30 to 300 colony-forming units. Data analysis of CFU considered the effects of flock, litter material, ventilation system, and their interactions and used the theory of mixed models for repeated measures and nine variance and covariance matrix structures applied to the PROC MIXED procedure of SAS statistical package (SAS, 2003).

\section{Results and Discussion}

According to statistical analysis results, flock, litter, and age significantly $(\mathrm{p}<0.05)$ influenced all evaluated parameters, whereas ventilation system had no effect on any variable. Two interactions significantly affected almost all parameters: litter $\times$ age and flock $\times$ ventilation $\times$ age (Table 1).

The details of the litter $\times$ age interactions indicated better results for rice husks litter as compared to soybean straw litter in all studied parameters at all ages (Table 2). These results are similar to those described by Mizubuti et al. (1994), who evaluated rice husks, guinea grass, and napier grass as litter material. On the other hand, opposite results were obtained by Mendes et al. (1987), Santos et al. (2000), Chamblee \& Yeatman (2003), Grimes et al. (2006), Atapattu \& Wickramasinghe (2007), Araújo et al. (2007), and Ávila et al. (2008), who tested different broiler litter materials and did not find any differences in body weight or feed intake. Moreover, Toghyani et al. (2009) studied five broiler litter materials and observed significant reduction of body weight, feed intake, and antibody titers in broilers reared on rice husks litter. Huang et al. (2009) compared the use of rice husks, coconut hulls, and wood shavings as broiler litter material and low- and high-density diets, and concluded that weight gain and feed intake during the total experimental period were higher in broilers reared on coconut hulls litter. 
Table 1 - Descriptive probability levels of the $\mathrm{F}$ test when analyzed by mixed models for repeated measures for feed intake, feed conversion ratio, weight gain, and body weight

\begin{tabular}{|c|c|c|c|c|}
\hline Causes of variation & Feed intake ${ }^{1}$ & Feed conversion ratio $^{2}$ & Weight gain $^{3}$ & Body weight $^{3}$ \\
\hline Flock & $<0.0001$ & $<0.0001$ & $<0.0001$ & $<0.0001$ \\
\hline Litter & $<0.0001$ & $<0.0001$ & $<0.0001$ & $<0.0001$ \\
\hline Ventilation & 0.5198 & 0.5937 & 0.6836 & 0.7136 \\
\hline Ventilation $\times$ litter & 0.1377 & 0.8415 & 0.1775 & 0.1808 \\
\hline Flock $\times$ litter & 0.1746 & 0.0047 & 0.6363 & 0.6517 \\
\hline Flock $\times$ ventilation & 0.6808 & 0.0051 & 0.0693 & 0.0704 \\
\hline Flock $\times$ ventilation $\times$ litter & 0.4874 & 0.0424 & 0.1657 & 0.1619 \\
\hline Age & $<0.0001$ & $<0.0001$ & $<0.0001$ & $<0.0001$ \\
\hline Litter $\times$ age & $<0.0001$ & 0.0519 & 0.0002 & 0.0002 \\
\hline Ventilation $\times$ age & 0.7124 & 0.1894 & 0.1616 & 0.1614 \\
\hline Flock $\times$ age & $<0.0001$ & $<0.0001$ & $<0.0001$ & $<0.0001$ \\
\hline Flock $\times$ ventilation $\times$ age & 0.6176 & 0.0033 & 0.0012 & 0.0012 \\
\hline Flock $\times$ litter $\times$ age & 0.2422 & 0.5549 & 0.6304 & 0.6301 \\
\hline Ventilation $\times$ litter $\times$ age & 0.4995 & 0.1159 & 0.0691 & 0.0689 \\
\hline
\end{tabular}

Variance and covariance matrix structures used: ${ }^{1}$ First-order antedependence; ${ }^{2}$ Banded; ${ }^{3}$ Self-regressive of the first heterogonous order.

Table 2 - Feed intake, feed conversion ratio, weight gain and body weight of broiler reared on two different litter materials and two different ventilation systems

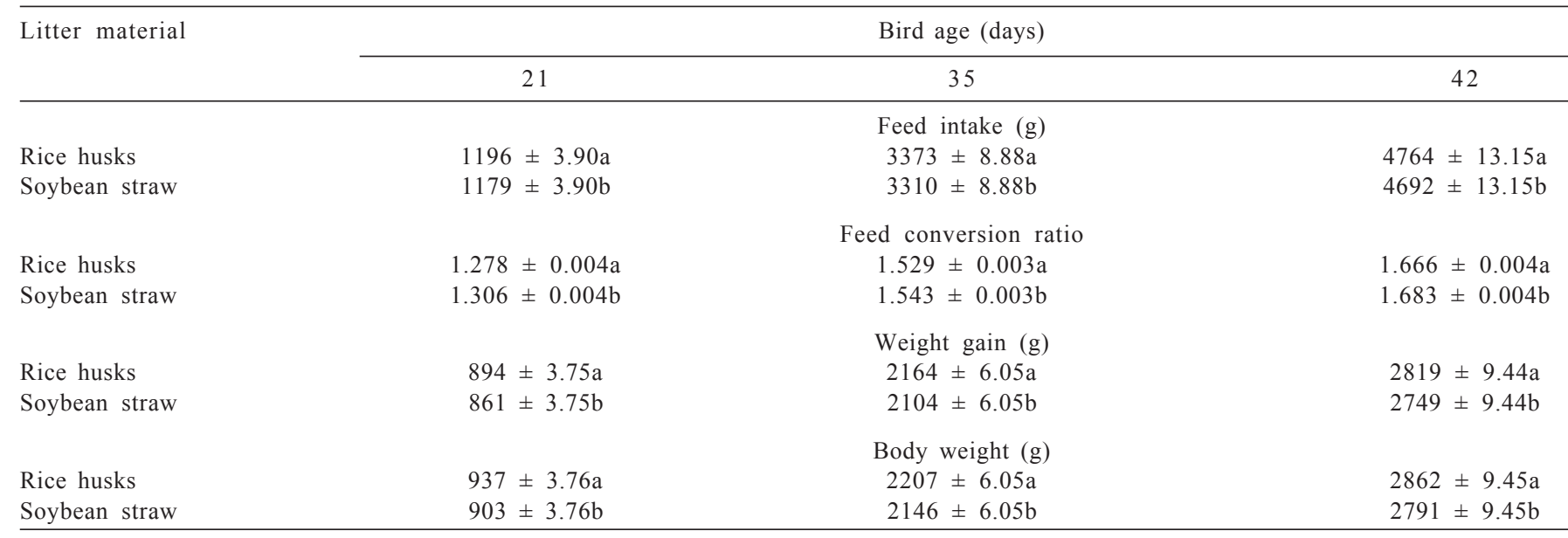

Means followed by different letters in the same columns are different $(\mathrm{p}<0.05)$ by $\mathrm{F}$ test.

The evaluation of the details of the triple interaction among flock, ventilation and age indicated that there was no consistent effect of ventilation system on performance parameters. When an effect of ventilation system was detected, it sometimes favored oscillating ventilation, the others, stationary ventilation (Table 3).

It is known that the capacity of the bird to dissipate heat is reduced when air temperature and relative humidity exceed environmental comfort ranges, directly influencing bird productivity. Depending on the magnitude and duration of the heat stress experienced by the birds, losses can range from small reductions in weight gain to mortality (Mitchell, 1987).

Body weight results at 42 days of age, when broilers are more susceptible to heat stress, clearly show that both stationary and oscillating ventilation were similar inasmuch as no statistical differences were found in any of the flocks. Despite the higher body weight obtained in broilers 35 days of age in flock 2 with the stationary fan and in flock 3 with the oscillating fan, this difference was not maintained when birds reached 42 days of age, showing that the flock recovered when removed to market. Feed conversion ratio values also support the hypothesis that both ventilation systems were similar, as differences were obtained only in flock 3 in favor of the oscillating ventilation.

The analysis of the presence of foot-pad lesion showed a significant influence $(p<0.0001)$ of the interaction between flock and litter and of the main effects litter and flock (Table 4).

Independently from the interaction, soybean straw litter caused higher incidence of foot-pad lesions as compared to rice husks, in all flocks (Figure 3). These results are opposite to those found in other studies evaluating litter materials that concluded that litter material has no effect on carcass lesions (Paganini, 2002). 
Table 3 - Feed intake, feed conversion ratio, weight gain and body weight of broilers reared on two different litter materials and two different ventilation systems

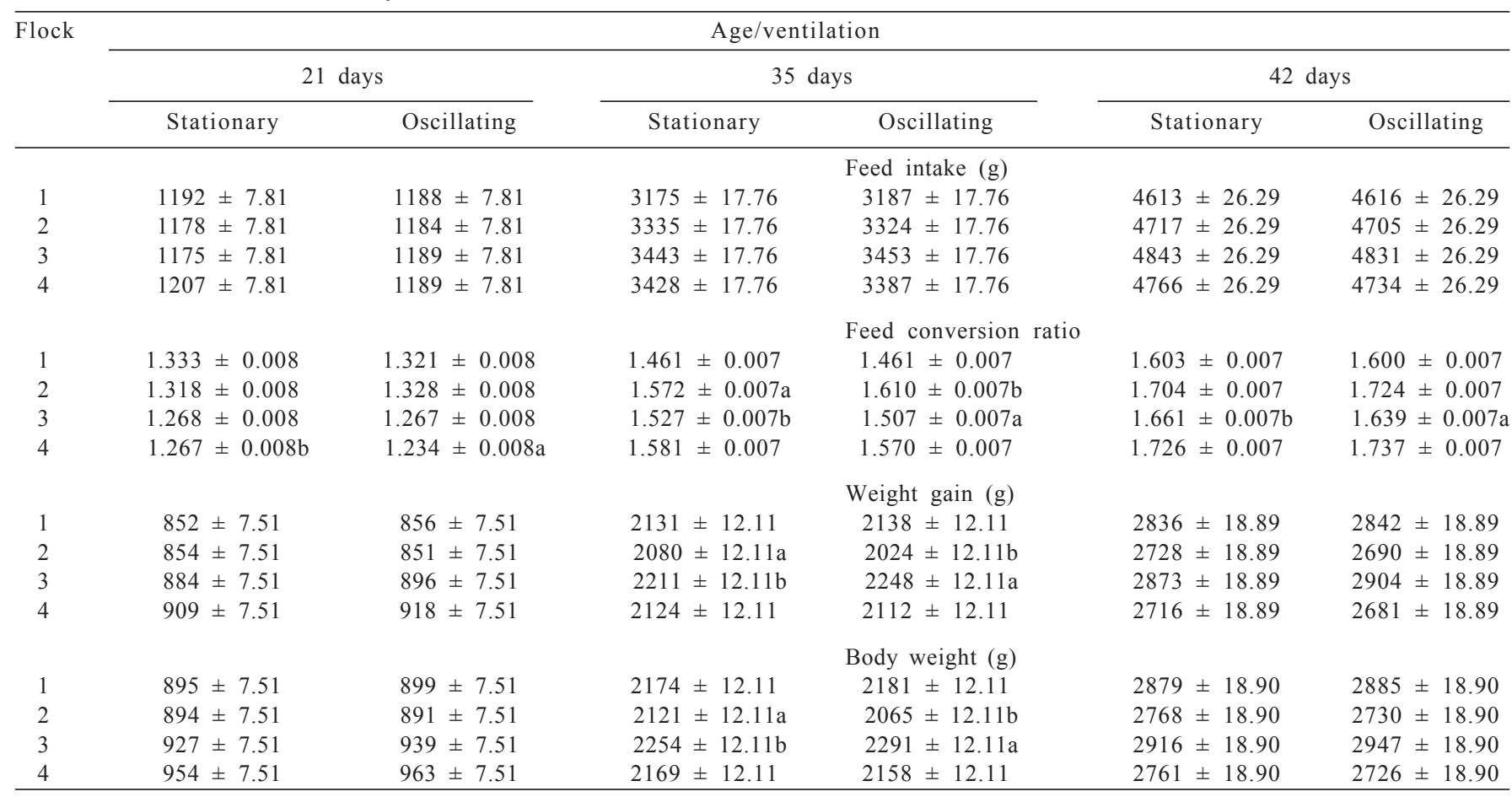

Means followed by different letters in the same columns are different $(\mathrm{p}<0.05)$ by the $\mathrm{F}$ test.

The obtained results indicate that litter material causes foot-pad lesions, resulting in carcass condemnation in the processing plant and consequent economic losses. Ângelo et al. (1997) also found higher incidence of foot-pad lesions when napier grass and coast-cross grass hays were used as litter material. However, Oliveira \& Carvalho (2002) used sunflower crop residue and brachiaria hay as litter, but did not find any effects on breast, hock, and foot-pad lesions. In the present study, it was also observed that the percentage of foot-pad lesions markedly increased from the first to the second flock, decreased in the third flock, and that this reduction was maintained in the fourth flock. Because the number of flocks increased, it is believed that clods litter was removed and the

Table 4 - Descriptive probability levels of $\chi^{2}$ test for the presence of foot-pad lesions and mortality

\begin{tabular}{lccc}
\hline Causes of variation & $\mathrm{DF}^{1}$ & Foot-pad lesions & Mortality \\
\hline Flock & 3 & $<0.0001$ & $<0.0001$ \\
Ventilation & 1 & 0.8235 & 0.9492 \\
Flock $\times$ ventilation & 3 & 0.4204 & 0.9291 \\
Litter & 1 & $<0.0001$ & 0.5640 \\
Flock $\times$ litter & 3 & $<0.0001$ & 0.0363 \\
Ventilation $\times$ litter & 1 & 0.7471 & 0.5946 \\
Flock $\times$ ventilation $\times$ litter & 3 & 0.4846 & 0.5806 \\
\hline
\end{tabular}

${ }^{1}$ Degrees of freedom. remaining the litter was turned, making litter softer, and thereby, reducing leg lesions.

Mortality was influenced by flock $(p<0.0001)$ and by the interaction between flock and litter $(\mathrm{p}<0.05)$. However, mortality was only significantly affected by litter material in the third flock in favor of soybean straw. Evaluating the use of wood shavings, rice husks, sugarcane residue and carnauba palm residue as broiler litter material, Azevedo et al. (2000) did not find any differences in mortality, although in absolute numbers, values were higher in broilers reared on wood shavings and sugarcane residue. Santos et al. (2000) and Toghyani et al. (2009) reported similar results, that is, no mortality differences in studies on alternative broiler litter materials.

According to Fioretin (2005), bacteria present in the litter may have different effects. Many gram-positive bacteria, such as lactobacilli and bifidobacteria, are present in broiler excreta and in the litter, but are not necessarily related to problems. On the other hand, the frequent presence of pathogens in the litter, particularly of enterobacteria and zoonotic bacteria in general, is a reason of concern due to possible diseases transmitted both to the broiler flock itself and to consumers. Moreover, according to Fiorentin (2005), the composition of the bacterial population in the litter is usually very similar to the composition of the 
physiological microbiota of the ileum of broilers, and it consists of approximately $70 \%$ lactobacilli, $11 \%$ Clostridium spp., 6.5\% Streptococcus spp., and 6.5\% Enterococcus spp. The litter presents, in average, 10 times less bacteria than the digesta, but this is still a high concentration of microorganisms. The digest contains between $10^{8}$ and $10^{10}$ of Gram-positive bacteria and $10^{6}$ to $10^{7} \mathrm{Gram}$-negative bacteria per gram. As the concentration of bacteria in the litter can increase 10 times per reared flock, it may achieve the same levels as the digesta. From the practical perspective, it can be assumed that bacterial concentration in the litter of broilers is similar to that in feces.

In the present study, total enterobacteria counts (expressed as colony-forming units, CFU) per gram of litter for each treatment were carried out when each of the four flocks was removed (day 42) and when the following flocks were housed (day 0), aiming at evaluating the effect of downtime on litter bacterial load.

Significant effects $(\mathrm{p}<0.05)$ of flock, evaluation day ( 0 or 42 ), and their interaction was observed, whereas litter material (rice husks or soybean straw) and ventilation system had no influence on litter enterobacterial load (Figures 4 and 5).

The evaluation carried out on day 42 always presented better results as compared to that performed on day 0 , as expected. However, the difference increased as the number of flocks increased (Figure 6), as shown by the lowest UFC count on day 42 (immediately after flock removal) in the third flock, whereas on day 0 (day of housing, after downtime), bacterial load was the lowest only in the fourth flock. This suggests that the reduction of the load of enterobacteria after downtime (day 0), may continue to occur in subsequente flocks, as the reduction was linear and did not achieve a stabilization point.

It must be mentioned that, during downtime, flamegun was used twice on the litter: immediately after bird removal and before the following flock was housed. However, during the 15-day downtime, litter was not submitted to any management practice for the reduction or control of undesirable bacteria, including potentially
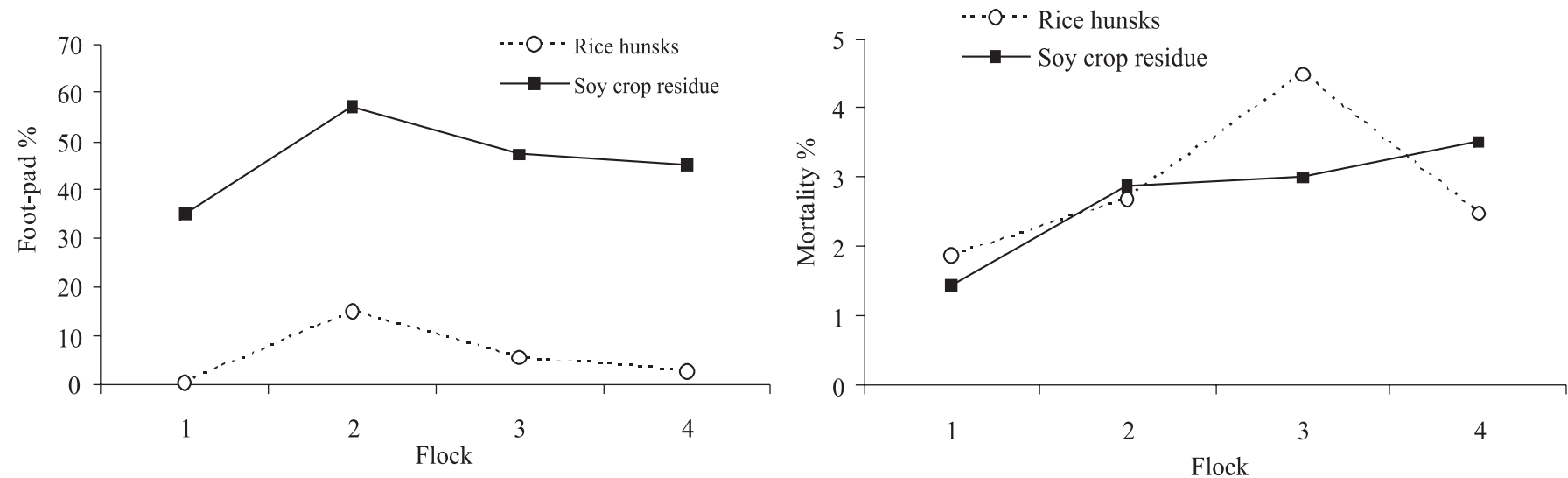

Figure 3 - Presence of foot-pad lesions and mortality rate of broilers reared on two different litter materials for four consecutive flocks.

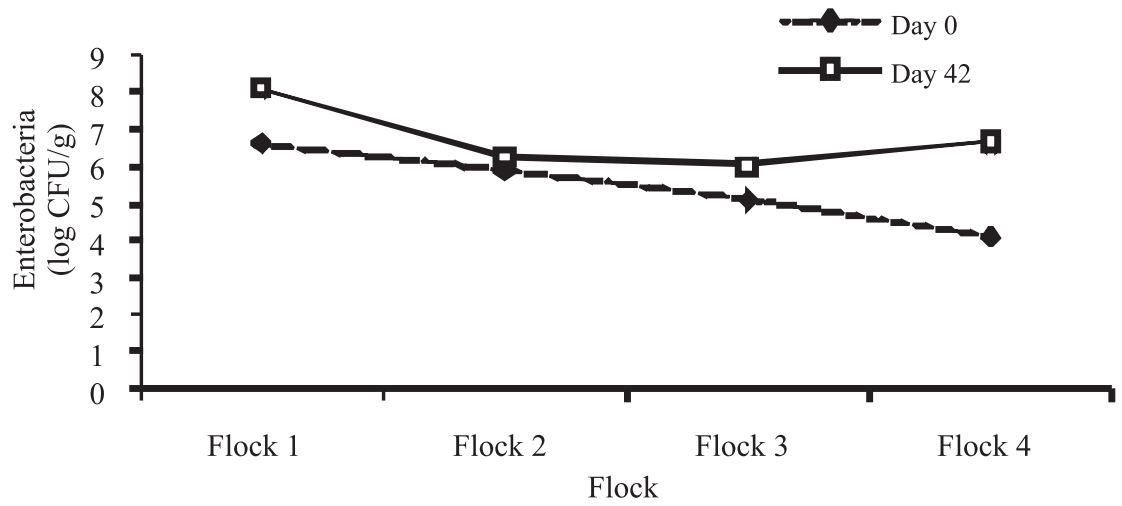

Figure 4 - Enterobacteria ( $\log \mathrm{CFU} / \mathrm{g}$ ) in rice husks litter reused for four broiler flocks (flock housing and removal - Days 0 and 42 ). 
pathogenic bacteria. Despite the reduction in the bacterial load along the four flocks, enterobacteria counts were high in all flocks, and therefore some method of litter treatment during downtime is recommended to reduce pathogen load. The initial enterobacteria counts in the litters used in the experiment before the first flocks were housed were considered high.

When evaluating litter treatment methods for bacterial load reduction, Silva et al. (2007) observed that average loads of enterobacteria and total mesophilles were high in new litters. According to those authors, these results call the attention to the quality of new litter, as high bacterial loads in that material are associated to their origin, possibly due to production, preservation, storage, and transport conditions to the broiler house. In addition, these high bacterial loads are a hazard to birds that will be housed in that environment, particularly considering they are 1-d old chicks.
Macklin et al. (2005) determined bacterial levels in pine shavings and sand used as broiler litter, and found a marked increase in bacterial counts after birds were housed. Pine shavings reached a level of $10^{8} \mathrm{CFU} / \mathrm{g}$ of aerobic bacteria in the second week, and this level remained stable up to six weeks, after which it increased approximately $1 \mathrm{log}$ the next week, and remained at this level until birds were removed at the seventh week. Enteric bacteria in pine shavings reach a plateau at $10^{7}$ to $10^{8} \mathrm{CFU} / \mathrm{g}$ in the second week, and these values showed little variation until the seventh week.

In the present study, enterobacteria counts were higher, in general, than those obtained in untreated wood shavings litter by Silva et al. (2007), which were about $10^{5} \mathrm{CFU} / \mathrm{g}$. Therefore, the need to treat the litter during downtime is stressed, independently of the material used.

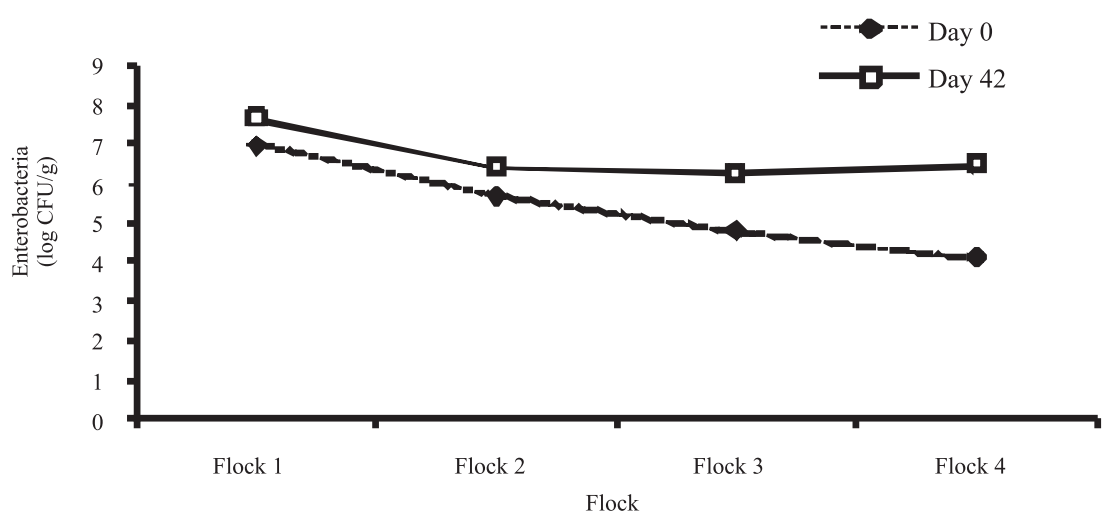

Figure 5 - Enterobacteria $(\log \mathrm{CFU} / \mathrm{g})$ in soybean straw litter reused for four broiler flocks (flock housing and removal - Days 0 and 42 ).

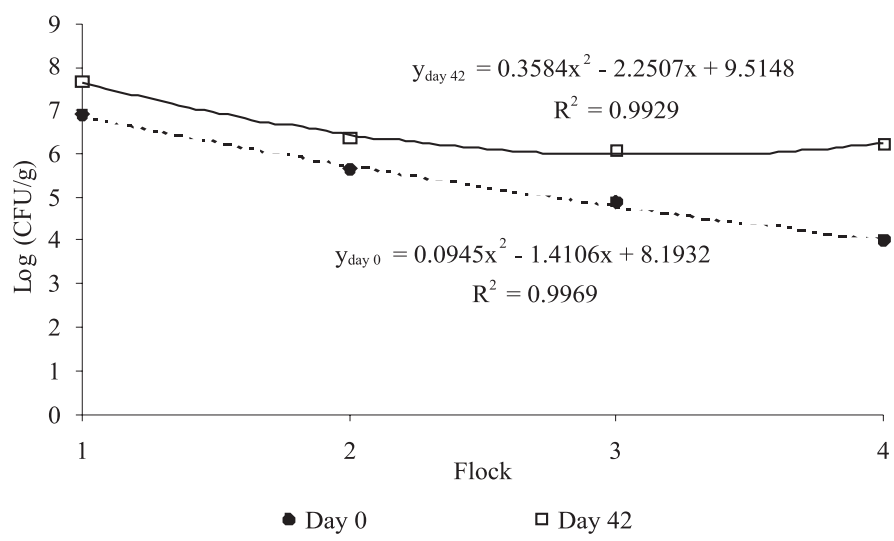

Figure 6 - Enterobacteria load on days 0 and 42 of the evaluated flocks, considering all treatments. 


\section{Conclusions}

Stationary and oscillating fans provide similar ventilation, and therefore, do not influence bird performance, mortality rate, the presence of foot-pad lesions or enterobacteria load in the litter. As compared to soybean straw, the use of rice husks as broiler litter material promotes better live performance of broilers up to 42 days of age. The use of soybean straw litter increases the incidence of footpad lesions relative to rice husks litter. Enterobacteria counts in broiler litter are reduced after downtime (day 0 ) when the litter is consecutively used by four flocks.

\section{Acknowledgements}

The authors thank Fundação de Apoio à Pesquisa de Santa Catarina - FAPESC, for funding this study, Unifrango Agroindustrial de Alimentos Ltda., in the person of the farmer Mr. Arsênio for supplying the litter material, and Roster Ind. e Com. Ltda for lending the fans.

\section{References}

ABREU, P.G.; ABREU, V.M.N. Ventilação na avicultura de corte. Concórdia: Embrapa Suínos e Aves, 2000. 50p. (Documentos, 63).

ANGELO, J.C.; GONZALES, E.; KONDO, N. et al. Material de cama: qualidade, quantidade e efeito sobre o desempenho de frangos de corte. Revista Brasileira de Zootecnia, v.26, n.1, p.121-130, 1997.

ARAÚJO, J.C.; OLIVEIRA, V.; BRAGA, G.C. Desempenho de frangos de corte criados em diferentes tipos de cama e taxa de lotação. Ciência Animal Brasileira, v.8, n.1, p.59-64, 2007.

ATAPATTU, N.S.B.M; WICKRAMASINGHE, K.P. The use of refused tea as litter material for broiler chickens. Poultry Science, v.86, n.5, p.968-972, 2007

AVILA, V.S.; OLIVEIRA, U.; FIGUEIREDO, E.A.P. et al. Avaliação de materiais alternativos em substituição à maravalha como cama de aviário. Revista Brasileira de Zootecnia, v.37, p.273-277, 2008.

AZEVEDO, A.R.; COSTA, A.M.; ALVES, A.A. et al. Desempenho produtivo de frango de corte de linhagem Hubbard, criados sobre diferentes tipos de cama. Revista Científica de Produção Animal, v.2, n.1, p.52-57, 2000.

CHAMBLEE, T.N.; YEATMAN, J.B. Evaluation of Rice hull ash as broiler litter. The Journal of Applied Poultry Research, v.12, n.4, p.424-427, 2003.

ELFADIL, A.A.; VAILLANCOURT, J.P.; MEEK, A.H.A. Prospective study of cellulitis in broiler chickens in Sourten Ontario. Avian Diseases, v.40, p.677-689, 1996.
FIORENTIN, L. Reutilização da cama de frangos e as implicações de ordem bacteriológica na saúde humana e animal. Concórdia: Embrapa suínos e Aves, 2005. 23p. (Documentos, 94).

GRIMES, J.L.; CARTER, T.A.; GODWIN, J.L. Use of a litter material made from cotton waste, gypsum and old newsprint for rearing broiler chickens. Poultry Science, v. 85 , v. 4 , p.563-568, 2006.

HUANG, Y.; YOO, J.S.; KIM, H.J. et al. Effect of bedding tipes and different nutrient densities on growth performance, visceral organ weight, and blood characteristics in broiler chickens. The Journal of Applied Poultry Research, v.18, n.1, p.1-7, 2009

JORGE, M.A.; MOUCHREK, E.; CARNEIRO, M.I.F. et al. Coliformes em cinco tipo de cama de frango em reutilização. Arquivo Brasileiro de Medicina Veterinária e Zootecnia, v.49, n.5, p.523-530, 1997

MACKLIN, K.S.; HESS, J.B.; BILGILI, S.F. et al. Bacterial levels of pine shavings na sand used as poultry litter. The Journal of Applied Poultry Research, v.14, n.2, p.238-245, 2005.

MENDES, A.A.; PATRICIO, I.S.; GARCIA, E.A. Utilização de fenos e gramíneas como material de cama para frangos de corte. In: CONGRESSO BRASILEIRO DE AVICULTURA, 10., 1987, Natal. Anais... Campinas: UBA, 1987. p.135.

MITCHELL, M.A.A. Some physiological effects of environmental temperature upon poultry. In: INTERNATIONAL POULTRY BUILDINGS CONFERENCE, 3., 1987, Londres. Proceedings... Londres: [s.n.], 1987. p.24-25.

MIZUBUTI, I.Y.; FONSECA, N.A.N.; PINHEIRO, J.W. Desempenho de duas linhagens comerciais de frangos de corte, criadas sob diferentes densidades populacionais e diferentes tipos de camas. Revista da Sociedade Brasileira de Zootecnia, v.23, n.3, p.476-484, 1994.

OLIVEIRA, M.C.; CARVALHO, I.D. Rendimento e lesões em carcaça de frangos de corte criados em diferentes camas e densidades populacionais. Ciência e Agrotecnologia, v.26, n.5, p. 1076-1081, 2002.

PAGANINI, F.J. Reutilização de cama na produção de frangos de corte: porquê, quando e como fazer. In: CONFERÊNCIA APINCO 2002 DE CIÊNCIA E TECNOLOGIA AVÍCOLAS, 2002, Campinas. Anais... Campinas: APINCO, 2002. p.194- 206.

SANTOS, E.C.; TEIXEIRA, C.J.T.B.; MUNIZ, J.A. et al. Avaliação de alguns materiais usados como cama sobre o desempenho de frangos de corte. Ciência e Agrotecnologia, v.14, n.4 p.1024-1030, 2000.

Silva, V.S.; VOSS, D.; COLdebella, A. et al. Efeito de tratamentos sobre a carga bacteriana de cama de aviário reutilizada em frangos de corte. Concórdia: Embrapa Suínos e Aves, 2007. 4p. (Comunicado Técnico, 467).

STATISTICAL ANALYSIS SYSTEM - SAS. System for Microsoft Windows: release 9.1. Cary, 2002-2003. (CD-ROM).

TOGHYANI, M.; GHEISARI, A.; MODARESI, M. et al. Effect of different litter material on performance and behavior of broiler chickens. Applied Animal Behaviour Science, v.122, p.48-52, 2009.

XAVIER, L.H. Modelos univariado e multivariado para análise de medidas repetidas e verificação da acurácia do modelo univariado por meio de simulação. 91f. 2000. Dissertação (Mestrado em Agronomia) - Escola Superior de Agricultura "Luiz de Queiroz", Piracicaba. 